\title{
Enzymatic, Morphological and Genotoxic Effects of Benzo[a]pyrene in Rainbow Trout (Oncorhynchus Mykiss)
}

Lara Fanali ( $D$ lara_zacari@hotmail.com )

São Paulo State University https://orcid.org/0000-0001-8678-6419

Classius de Oliveira

Sao Paulo State University Julio de Mesquita Filho: Universidade Estadual Paulista Julio de Mesquita Filho

Joachim Sturve

University of Gothenburg: Goteborgs Universitet

\section{Research Article}

Keywords: cytoskeleton, melanomacrophage, EROD, morphological alteration, liver, erythrocytes abnormalities

Posted Date: March 15th, 2021

DOl: https://doi.org/10.21203/rs.3.rs-169132/v1

License: (a) This work is licensed under a Creative Commons Attribution 4.0 International License. Read Full License 


\section{Abstract}

Fish have defense systems that are capable of repairing damages caused by xenobiotics like benzo[a]pyrene (BaP), so the aims of this study were to identify BaP toxicity in melanomacrophages (MMs) cytoskeleton, evaluate the melanin area in MMs and analyze genotoxicity. Rainbow trout juveniles $(\mathrm{n}=24)$ were split in $48 \mathrm{~h}$ and $7 \mathrm{~d}$ treatments that received $2 \mathrm{mg} / \mathrm{kg}$ of BaP. After the experiment, blood samples were collected and liver was removed, to proceed with the analysis: EROD activity, MMs melanin area quantification, melanosomes movements, and a genotoxicity test. The results revealed increased in EROD activity after $48 \mathrm{~h}$ and $7 \mathrm{~d} \mathrm{BaP}$ exposure. The group $7 \mathrm{~d}$ displayed a reduction in MMs pigmented area, melanosomes aggregation, in addition to an increased frequency of micronuclei. By means of the EROD assay, it was possible to confirm the activation of BaP biotransformation system. The impairment of the melanosomes' movements possibly by an inactivation of the protein responsible for the pigment dispersion consequently affects the melanin area and thus might negatively impact the MMs detoxification capacity. In addition to this cytotoxicity, the increased frequency of micronucleus might also indicate the genotoxicity of $\mathrm{BaP}$ in this important fish species.

\section{Introduction}

Polycyclic Aromatic Hydrocarbons (PAHs) are originated from incomplete combustion processes of carbonaceous materials performed by humans, during energy generation and other industrial processes (Curtis et al. 2011), such as the combustion of fossil fuels, petroleum spills, and industrial effluents (Whyte et al. 2000; Santana et al. 2018). Although natural sources of PAHs exist, such as forest fires and natural petroleum sources, the main source of contamination is anthropogenic (Whyte et al. 2000; Santana et al. 2018). Fish and other aquatic organisms can be exposed to PAHs through the gills (respiration), guts (ingestion) or by means of contact through its integument (dermal contact) (Logan 2007). Therefore, several PAHs, such as benzo[a]pyrene (BaP), are of great concern when it comes to the health of aquatic organisms.

Benzo[a]pyrene is a hepatotoxic (Pastore et al. 2014; Regnault et al. 2014, 2016; Fanali et al. 2018) and genotoxic PAH (Mouchet et al. 2005; Fanali et al. 2018), being widely studied due to its bioconcentration capacity (Connel 1990; Logan 2007), extensive distribution (Douben 2003; Head et al. 2015), toxicity (Brandt et al. 2002; Head et al. 2015; Santana et al. 2018) and persistence in the environment (Brandt et al. 2002; Collier et al. 2013).

Aquatic organisms have molecular and cellular defense systems (e.g. detoxifying enzymes and molecules) to protect themselves against harmful effects of xenobiotics (Sturve et al. 2014). Cellular and molecular damages caused by exposure to these substances are often used in monitoring and assessment programs addressing the environmental impact of pollutants (van der Oost et al. 2003; Sturve et al. 2014). Interactions between pollutants and both biochemical and physiological functions in fish that result in organ-to-subcellular level disturbances, are designated biomarkers and can be used as 
warning signs, indicating possible alterations in its homeostasis, such as altered reproduction, growth, and even its survival (Forlin et al. 1986; Haux and Forlin 1988; Sturve et al. 2014).

Biological responses to PAHs toxicity can be assessed by measuring the induction of hepatic CYP1A activity. CYP1A expression is induced by the Ah receptor that binds with dioxin-like compounds, planar PCBs and PAHs (Goksøyr and Forlin 1992; Abrahamson et al. 2007; Sturve et al. 2014). CYP1A activity can be measured by means of the ethoxyresorufin-O-deethylase (EROD) activity, a widely used technique in fish species (Goksøyr and Forlin 1992; Bend 1994; Bargagli et al. 1998; Whyte et al. 2000; Bonacci et al. 2003; Sturve et al. 2014). Thus, EROD activity serves as a sensitive biomarker for PAHs including BaP (Pacheco and Santos 1998; Whyte et al. 2000).

Melanomacrophages (MMs) are hepatic phagocytic macrophages present in fish, amphibians and reptiles (Wolke 1992; Fournie et al. 2001; Loumbourdis and Vogiatzis 2002; Fenoglio et al. 2005; Fishelson 2006; Bach et al. 2018) that produce and store melanin (Agius and Roberts 2003; Ribeiro et al. 2011), which enables an antioxidant function to these cells (Fenoglio et al. 2005; Bach et al. 2018). Melanin neutralizes free radicals, cations and other toxic agents produced during the degradation of phagocyted cell material (Zuasti et al. 1989). The MMs' melanin production is performed by the melanosome (Sichel et al. 1997), an organelle that contains melanogenic enzymes, i.e. that is capable of producing melanin (Colombo et al. 2011).

MMs accumulate exogenous materials from both natural and experimental origins (Steinel and Bolnick 2017) and are also responsive in face of the action of xenobiotics (Regnault et al. 2014, 2016; FrancoBelussi et al. 2016; de Oliveira 2017; Fanali et al. 2017, 2018), thus being involved in detoxification processes, due to a combination of enzymatic biotransformation and antioxidant actions (Fenoglio et al. 2005; Bach et al. 2018). This gives them the ability to detoxify cytotoxic substances through the melanic biopolymer (Fenoglio et al. 2005; Bach et al. 2018).

Pigment cells are excellent models to study the transport of organelles, as these are responsible for the translocation of pigment granules in response to specific chemical signals (Aspengren et al. 2006). Toxicological effects in components of the cytoskeleton such as microtubules and actin filaments were previously studied in pigmented cells called melanophores, seen that these components are evolutionarily well-conserved (Aspengren et al. 2006, 2012; Hedberg and Wallin 2010). However, the MMs cytoskeleton was never use to assess effects of contaminants on the movement of melanosomes.

Environmental stressors and contaminants are able to impair the cytoskeleton, thus compromising the aggregation and dispersion of melanin granules (Aspengren et al. 2006, 2008; Hedberg and Wallin 2010). Such a prejudice to the cytoskeleton is known to jeopardize the detoxification function of MMs, as it compromises the cell's integrity. Additionally, genotoxic substances like BaP can damage the genetic material of cells through interactions with the DNA structure (Kaur et al. 2018), which may result in the formation of micronucleus (MN) (Kaur et al. 2018) and other nuclear erythrocytes abnormalities (Pacheco and Santos 1998; Peixoto et al. 2019). 
Rainbow trouts (Oncorhynchus mykiss) has been used as model fish species in several studies concerning the effects of toxic substances in its metabolic activity and cytotoxicity (Laville et al. 2004; Schreer et al. 2005; Ellesat et al. 2010). Considering the known toxicity of BaP and based on the hypothesis that $\mathrm{BaP}$ disrupts MMs cytoskeleton, altering the movement of melanosomes, our aims were to evaluate the effects of $\mathrm{BaP}$ in the MMs melanin area, in order to deduce how the compound can affect the cell's functionality, to identify toxic effects in actin filaments and microtubules, and to assess the activity of EROD, in order to analyze the BaP-mediated activation of the biotransformation system. Genotoxicity was analyzed by erythrocytes abnormalities (anucleate, binucleated, MN and bud).

\section{Material And Methods}

\section{Experiment with benzo[a]pyrene}

Rainbow trout juveniles ( $\mathrm{n}=24)$ with an average weight and length of $70 \mathrm{~g}$ and $190 \mathrm{~mm}$, originating from Vänneåns Laxodling, Halmstad, Sweden, were used for the exposure experiments with BaP (Sigma Aldrich, St Louis). The experimental design consisted in two treatments, one received BaP and the other receiving only the vehicle (control), and two exposure times of 48 hours and 7 days. Therefore, the group $48 \mathrm{~h}$ received a single intraperitoneal injection of $\mathrm{BaP}(2 \mathrm{mg} / \mathrm{kg}$, dissolved in peanut oil), while the group denominated $7 \mathrm{~d}$ received 3 injections with 2-days intervals. The control groups received the same injections, which contained only the peanut oil. The animals were kept in a water-recirculation system with constant aeration $\left(12^{\circ} \mathrm{C}\right)$ under a natural night and daylight regime $(12 \mathrm{~h} / 12 \mathrm{~h})$ in glass tanks without being fed. The chosen concentration of BaP was based on the study developed by Padrós et al. (2003), with adaptations.

At the end of the experiment, the animals were euthanized with a blow to the head and had their weight and length recorded. Blood was collected from the caudal vein and the liver excised. The liver was shockfrozen and stored on liquid nitrogen until preparation for analysis. All procedures described in this study were conducted according to Swedish ethics guidelines, in accordance with the Ethics permit 159862018.

\section{EROD assay}

Livers were homogenized in a cold homogenizing buffer solution $(0.1 \mathrm{M} \mathrm{Na} / \mathrm{P}$ - phosphate buffer containing $0.15 \mathrm{M} \mathrm{KCl}, \mathrm{pH} 7.4$ ). The homogenate was centrifuged at $10,000 \mathrm{~g}$ during $20 \mathrm{~min}$ at $4{ }^{\circ} \mathrm{C}$. The supernatant was centrifuged again for $100,000 \mathrm{~g}$ for $60 \mathrm{~min}$ at $4^{\circ} \mathrm{C}$, in order to prepare the microsomal fraction. Subsequently, the supernatant (cytosol) was stored at $-80^{\circ} \mathrm{C}$ until use. The pellet (microsomes) was re-suspended in the homogenizing buffer solution containing $20 \%$ glycerol and stored at $-80^{\circ} \mathrm{C}$.

The EROD activity was measured in the microsomal fraction of the liver, according to the method described by Förlin et al. (1986) using rhodamine as standard. The reaction mixture contained sodium phosphate buffer $(0.1 \mathrm{M}, \mathrm{pH} 8.0)$, ethoxyresorufin $(0.5 \mathrm{mM})$, and 25 to $50 \mathrm{ml}$ of sample in a final volume of $2 \mathrm{ml}$. The reaction began with the addition of $10 \mathrm{ml}$ of NADPH $(10 \mathrm{mM})$. The increase in fluorescence 
was monitored at $530 \mathrm{~nm}$ (excitation) and $585 \mathrm{~nm}$ (emission). EROD activity was expressed as picomoles of resorufin formed per minute and per milligram of protein ( $\mathrm{pmol} / \mathrm{min} / \mathrm{mg}$ protein). For this purpose, the protein content was quantified according to Lowry et al. (1951) using bovine serum albumin (BSA) as standard.

\section{Quantification of melanin}

In regard to the histological analysis, liver fragments were fixed in Metacarn (60\% methanol, 30\% chloroform, 10\% acetic acid) for 3 hours, dehydrated in alcoholic series, embedded in paraffin and stained with Hematoxylin-Eosin. 25 random pictures were taken from each animal under a light microscope, with the aid of an image capture system. Then, the quantification of the pigmented area was carried out by the difference in color intensity observed in MMs as suggested by Santos et al. (2014), using the software Image Pro-Plus (version 6.0).

\section{Cytoskeleton analysis}

Liver samples were frozen at $-20^{\circ} \mathrm{C}$ prior to analysis, and after thawing, fragments of the organ were placed in $2 \mathrm{~mL}$ of an EDTA solution ( $2 \mathrm{mM}$ ) for up to $24-48 \mathrm{~h}$ at $4{ }^{\circ} \mathrm{C}$, in order to dissociate liver cells and separate MMs. This step allows cells to be dissociated by mechanical action of continuous suctioning of its contents. Subsequently, the content was centrifuged at $1,500 \mathrm{~g}$ for $10 \mathrm{~min}$ at $4{ }^{\circ} \mathrm{C}$ for pellet formation. Pellets containing MMs were dissolved in $\mathrm{KCl}(0.56 \% \mathrm{w} / \mathrm{v})$ for $20 \mathrm{~min}$ and mixed during 10 s to suspend the pellet.

Regarding microtubules immunostaining process, the cells were fixed in ice methanol for 6 min and then washed three times during 5 min with PBS (phosphate buffered saline), before being incubated with the primary antibody Rabbit polyclonal to beta tubulin - Loading control (Abcam) for $60 \mathrm{~min}$ at room temperature. The cells were then washed three times during 5 min with PBS and incubated in the darkness with the secondary antibody Goat polyclonal to rabbit lgG - H\&L (Alexa Fluor® 488) (Abcam) for $45 \mathrm{~min}$. Finally, cells were again washed three times during $5 \mathrm{~min}$ with PBS and underwent a final rinse in miliQ water, in the attempt to avoid the formation of salt crystals before they were allowed to dry (Hedberg and Wallin 2010).

The analysis of actin filaments was performed by initially rinsing cells in PBS, followed by fixation in a $3.7 \%$ formaldehyde solution for 10 min, then washing it twice with PBS, and permeabilized with $0.1 \%$ Triton X-100 for $5 \mathrm{~min}$. The slides were then washed again twice for $5 \mathrm{~min}$ in PBS, and blocked with 1\% BSA for $20 \mathrm{~min}$. The cells were then stained with Rhodamine-Phalloidin (Thermo-Fisher) for $20 \mathrm{~min}$, washed three times for 5 min in PBS, rinsed in miliQ water and dried (Hedberg and Wallin 2010).

A total of 50 cells per animal were counted under a Nikon Eclipse E100 fluorescence microscope, using the ACT-1 (version 2.0) software. The quantification was made by the measurement of the fluorescent cell area, using the software Image Pro-Plus (version 6.0). 


\section{Nuclear abnormalities analysis}

Upon euthanasia, blood was collected from the caudal vein with a heparinized syringe and needle, dripped onto a slide and blood smears were made. After drying, slides were fixed in methanol for 20 min and stained with Giemsa $7.5 \%$, for 30 min. The following nuclear abnormalities in erythrocytes were analyzed: anucleate, binucleated, bud and MN. For each animal, 1000 erythrocytes were counted, as suggested by Pérez-Iglesias et al. (2014).

\section{Statistical analysis}

The experimental design consisted of two treatments (control and one BaP concentration) and two exposure times (48 hours and 7 days), which characterizes a $2 \times 2$ factorial design. Six animals were used in each treatment for the quantification of EROD activity, cytoskeleton, MMs and erythrocytes abnormalities.

A Kruskal-Wallis test was applied in the EROD assay, in order to determine whether significant differences among groups existed, seen that the data did not present a normal distribution.

A Linear Mixed-Effects Model (package Ime4; Bates et al. 2015) (Zuur et al. 2009) with restricted maximum likelihood (REML; Bolker et al. 2009) considering treatment and time of exposure as fixed factors along with their interaction, was applied to model microtubules, actin filaments and MMs area, considered as continuous responses variables. Sampling units (cells for microtubules and actin filaments; pictures for MMs area), in which we estimated the response variables, were nested within each animal (true replicate). To control the dependency among 50 cells or 25 pictures from the same animal (Crawley 2012: 703), we included a random intercept for animal (categorical with 6 levels; Moen et al. 2016). Then, in order to test the model's assumptions, we used diagnostic plots with the R package sjPlot (Lüdecke 2016) and to assess for differences between treatment and exposure time we used leastsquares means with $\mathrm{R}$ package Ismeans (Lenth 2016). Microtubule analysis data were log-transformed, aiming to attend the assumptions of normality and homogeneity. Then, the statistical models were summarized and, as suggested by Kenward and Roger (1997), P values were estimated based on conditional F-tests, with the approximations of degrees of freedom being made with the aid of the sjPlot.

A Generalized Linear Model (GLM) was used to model erythrocytes abnormalities. A binomial distribution and log link function included treatment and exposure time, along with their interactions. To test model assumptions we used diagnostic plots from the R (Team Core 2016) sjPlot package (Lüdecke 2016). All analysis were performed using software R v. 3.3.2 (R Core Team 2016).

\section{Results}

\section{EROD activity}


Results show that EROD activity was significantly induced after both exposure times, 48 hours and 7 days. After 48 hours, the activity increased from $175.8 \pm 48.8 \mathrm{pmol} / \mathrm{min} / \mathrm{mg}$ to $849.8 \pm 153.6$ $\mathrm{pmol} / \mathrm{min} / \mathrm{mg}$, i.e., $3.835 \mathrm{x}(\mathrm{p}<0.05)$ (Fig. 1). Similarly, the activity increased from $38.5 \pm 16.5$ $\mathrm{pmol} / \mathrm{min} / \mathrm{mg}$ to $144.2 \pm 30.3 \mathrm{pmol} / \mathrm{min} / \mathrm{mg}$ after 7 days, i.e., $2.747 \mathrm{x}(\mathrm{p}<0.05)$ (Fig. 2).

\section{Melanin area of melanomacrophages}

The presence of BaP did not exert significant effects on the area of melanin ( $p>0.05)$ after $48 \mathrm{~h}$. After 7 days of exposure, the melanin area of MMs was reduced from $91.0 \pm 31.9 \mu \mathrm{m}^{2}$ to $64.4 \pm 28.3 \mu \mathrm{m}^{2}$, which represents a reduction of $29.2 \%(F=0.8965, p<0.01)$ (Fig. 3$)$.

\section{Cytoskeleton}

After 48 hours of exposure we did not observe significant effects of $\mathrm{BaP}$ in fluorescent cell area $(\mathrm{p}>0.05)$. After 7 days, the fluorescent cell area corresponding to actin filaments decreased from $7915.9 \pm 1305.9$ $\mu \mathrm{m}^{2}$ to $5058.0 \pm 901.1 \mu \mathrm{m}^{2}$, which means that melanin granules were $36.1 \%(F=26.0756, p<0.01)$ more aggregated in the treated group in comparison to the control (Figs. 4-5). In relation to microtubules, no significant differences were observed among groups ( $p>0.05$ ) (Figs. 6-7).

\section{Nuclear Abnormalities}

Regarding the group exposed for 48 hours to BaP, no significant differences were found in relation to nuclear abnormalities. Differently, after 7 days of exposure, a $30 \%$ higher frequency of $\mathrm{MN}$ was observed $(p<0.05)$ (Table 1, Fig. 8).

Table 1. Nuclear abnormalities found in erythrocytes of Rainbow trout exposed to $2 \mathrm{mg} / \mathrm{kg}$ of benzo[a]pyrene.

\begin{tabular}{|cccccc|}
\hline & Anucleate & Micronucleus & Binucleated & Bud & Total Abnorm. \\
\hline Cont 48h & $0.3 \pm 0.3$ & $0.6 \pm 0.3$ & $0.5 \pm 0.5$ & $0.3 \pm 0.3$ & $0.4 \pm 0.3$ \\
\hline BaP 48h & $0.5 \pm 0.5$ & $1.1 \pm 0.4$ & $0.3 \pm 0.2$ & $0.6 \pm 0.3$ & $0.6 \pm 0.3$ \\
\hline Cont 7d & $1.0 \pm 0.5$ & $0.5 \pm 0.2$ & $0.8 \pm 0.4$ & $1.0 \pm 0.4$ & $0.8 \pm 0.4$ \\
\hline BaP 7d & $0.5 \pm 0.3$ & $2.0 \pm 0.5^{\star}$ & $0.6 \pm 0.4$ & $0.8 \pm 0.5$ & $1.0 \pm 0.5$ \\
\hline
\end{tabular}

Significant differences between control and treated groups are shown with the asterisk $\left({ }^{\star}\right)$. $P<0.05$.

\section{Discussion}

Results from the present study show that EROD activity was increased in the BaP exposed animals, possibly due to an induction of CYP1A, results that are supported by other studies. The species Oryzias 
latipes exposed to 0.5 and $5 \mu \mathrm{g} \mathrm{BaP}$ for 48 hours displayed augmented EROD activity (Pannetier et al. 2019) and studies with flounder and rainbow trouts revealed the same response after several days of exposure with 10 and $50 \mathrm{mg} / \mathrm{kg} \mathrm{BaP}$ (Malmström et al. 2004). Eelpouts exposed to three different doses of bunker oil containing around $25 \%$ PAHs $\left(10,100\right.$, and $\left.1,000 \mu \mathrm{g} \mathrm{L}^{-1}\right)$ also exhibited increased EROD activity (Sturve et al. 2014). Curtis et al. (2011) showed increase hepatic microsomal EROD activity after 3 and 14 days in rainbow trout exposed to $3 \mu \mathrm{g} \mathrm{BaP/g}$ fish/day. Ethoxyresorufin 0-deethylase is characterized to be sensitive to induction by Ah receptor binding chemicals such as PAHs (Pacheco and Santos 1998). BaP binds to the Ah receptor, which is translocated to the nucleus, where the transcription of CYP1A occurs, an enzyme responsible for EROD activity (Whyte et al. 2000).

The increase in EROD activity demonstrates the induction of CYP1A, which in turn is responsible for the metabolization of BaP (Whyte et al. 2000). In the metabolization of lipophilic xenobiotics such as BaP, the formation of water-soluble products of low toxicity is expected (Goksøyr and Förlin 1992; Bonacci et al. 2003). However, during the processes of hepatic biotransformation, which is mostly catalyzed by the enzyme cytochrome P450 1A1 (CYP1A1) (Caruso and Alaburda 2008; Wakx et al. 2016), higher concentrations of toxic byproducts such as 7,8-dihydroxy-9,10-epoxy-7,8,9,10-tetra (a) pyrene (BPDE) may be formed (Madureira et al. 2014).

After 7 days of $\mathrm{BaP}$ exposure, the melanosomes of MMs were more aggregated, according to the smaller fluorescent cell area corresponding to actin filaments; additionally, the melanin area of MMs was found to be reduced. The basic principle for the intracellular transport of melanosomes involves microtubules and actin filaments, cytoskeletal components as a molecular engine on melanosomes, and the presence of the kinesin and dynein proteins, as a mode for transporting (Alberts et al. 2002). The cytoplasmic protein dynein is involved in the movement of melanosomes by microtubules towards the nuclei, while kinesin disperses the granules throughout microtubules (Bagnara and Matsumoto 2006; Sköld et al. 2002, 2016).

In the anuran Xenopus laevis, the removal of actin filaments from melanophores inhibits the dispersion of melanosomes (Aspengren et al. 2006; McGuire et al. 1972), and those filaments are essential for pigment dispersion in these cells (Rogers et al. 1999). Actin filaments may be disrupted in dispersed melanophores, which leads to melanosomes aggregation in the cell centre (Rogers et al. 1998, 1999; Aspengren et al. 2006). Drugs (e.g. cytochalasin B) are also capable of inducing pigment aggregation by causing actin disruption (Koyama and Takeuchi 1980; Aspengren et al. 2008).

Even though the rupture of actin filaments leads to the aggregation of pigments in anurans, the opposite happens in fish (Sköld et al. 2002; Aspengren et al. 2008). However, the motor protein kinesin, which is involved in the dispersion of melanosomes in fish (Rodionov et al. 1991), is regulated and activated by the cyclic adenosine monophosphate (cAMP) signal cascade (Sköld et al. 2002), a second messenger responsible for regulating pigment translocation in most melanophores (Tuma and Gelfand 1999). Low levels of cAMP lead to kinesin motor inactivation and cell aggregation (Rozdzial and Haimo 1986; Sammak et al. 1992; Sköld et al. 2002). Yeo et al. (2017) reported that BaP administration decreased 
cAMP levels in tumors with adjacent lung tissues, while in our study, BaP may have triggered a similar response in relation to low levels of cAMP, which prevented kinesin activation and maintained the melanosomes of MMs aggregated.

In relation to the reduction of the melanin area of MMs, Pronina et al. (2014) reported similar results in the common Roach (Rutilus rutilus) from a lake contaminated with cyanobacteria microcystin, while Payne and Fancey (1989) observed a decreased number of MMs in the liver of Pseudopleuronectes americanus kept in tanks with high levels of PAHs. The anuran Hypsiboas albopunctatus exposed to 7 $\mathrm{mg} / \mathrm{kg} \mathrm{BaP}$ for 3 days (Fanali et al. 2017) and Physalaemus cuvieri and Leptodactylus fuscus anurans exposed to $2 \mathrm{mg} / \mathrm{kg} \mathrm{BaP}$ for 7 days (Fanali et al. 2018) showed the same reduction of melanin area. A possible explanation for these results is suggested by Joo et al. (2015), who observed that BaP inhibits the tyrosinase activity, an enzyme responsible for the regulation of melanogenesis, induced by the melanocyte stimulating hormone (a-MSH) (Park et al. 2009; Videira et al. 2013), and consequently decreases melanin synthesis (Joo et al. 2015). Another explanation is based on the results obtained in our study regarding the analysis of actin filaments, where it was possible to observe an aggregation of melanosomes in the center of the cell, which may have triggered a reduction of melanin area of the MMs.

$\mathrm{BaP}$ exposure also led to an increased frequency of $\mathrm{MN}$ after 7 days of exposure. $\mathrm{MN}$ analyses is a widely applied method to study genotoxicity since it is a convenient, sensitive and easy applicable method, in particular for genotoxicological studies with aquatic organisms (Kaur et al. 2018). A recent study indicated increased frequency of $\mathrm{MN}$ in brown trouts (Salmo trutta fario) captured in a polluted river contaminated mostly by PAHs (Hariri et al. 2018). In vitro studies utilizing the rainbow trout liver cell line RTLW1, revealed that the exposure to the PAHs carbazole, acridine and dibenzothiophene, resulted in increased MN frequency, suggesting genotoxic impact (Brinkmann et al. 2014). In Oreochromis niloticus exposed to nitrated PAHs, MN frequencies were significantly higher in the exposure groups after 7 and 14 days (Bacolod et al. 2017). Similarly, two anuran species (Physalaemus cuvieri and Leptodactylus fuscus) exposed to $2 \mathrm{mg} / \mathrm{kg} \mathrm{BaP}$ had increased frequency of MN after 7 days (Fanali et al. 2018). Taken together, the results presented in this study and previously published studies clearly show that BaP has genotoxic potential.

\section{Conclusion}

The reduced melanin area of MMs is associated with the aggregation of melanosomes, evidenced by the decrease in the fluorescent cell area, corresponding to the actin filaments. This is the first study that evaluated cytoskeleton components in the attempt of explaining the reduced area of MMs after exposure by a contaminant, when the expected would be an increase in this cell's area, due to its detoxification function. Our hypothesis was partly corroborated, as we demonstrated that BaP has an influence on the cytoskeleton and alters the movement of melanosomes, not by disrupting the components of the cytoskeleton, but possibly by an inactivation of the protein responsible for the pigment dispersion. Further studies are necessary to elucidate these mechanisms. Considering that $\mathrm{BaP}$ induced an increase in the 
frequency of $\mathrm{MN}$, it was concluded that this contaminant is genotoxic to rainbow trouts at a level of $2 \mathrm{mg} / \mathrm{kg}$.

\section{Declarations}

\section{Ethical Approval}

All procedures described in this study were conducted according to Swedish ethics guidelines, in accordance with the Ethics permit 15986-2018.

\section{Consent to Participate}

Not applicable.

\section{Consent to Publish}

Not applicable.

\section{Authors' contributions}

LZF: conceptualization, investigation, methodology, data collection, writing original draft, and review. CO: conceptualization, resources, writing original draft, review and editing. JS: methodology, resources, formal analysis, review and editing. All authors read and approved the final manuscript.

\section{Acknowledgment}

The authors thank Margareta Wallin for the assistence with the cytoskeleton methodology and text revision.

\section{Funding}

This study was supported by Fundação de Amparo à Pesquisa do Estado de São Paulo (FAPESP) (grants \#2013/02067-5 and \#2018/01078-7). CO has been continuously supported by CNPq (fellowships \#305081/2015-2 and \#304552/2019-4). Thanks also to FAPESP for BEPE fellowship (2018/07989-1) to LZF.

\section{Competing interests}

The authors declare that they have no competing interests.

\section{Data availability}

The datasets used and/or analyzed during the current study are available from the corresponding author on reasonable request. 


\section{References}

1. Abrahamson A, Andersson C, Jönsson ME, Fogelberg O, Örberg J, Brunström B, Brandt I (2007) Gill EROD in monitoring of CYP1A inducers in fish-A study in rainbow trout (Oncorhynchus mykiss) caged in Stockholm and Uppsala waters. Aquat Toxicol 85(1):1-8

2. Agius C, Roberts RJ (2003) Review: Melano-Macrophage Centres and their Role in Fish Patology. J Fish Biol 26:499-509

3. Alberts B, Johnson A, Lewis J, Raff M, Roberts K, Walter P (2002) Molecular Biology of the Cell, 4th edn. Garland Science, New York. p1616

4. Aspengren S, Hedberg D, Sköld HN, Wallin M (2008) New insights into melanosome transport in vertebrate pigment cells. Int Rev Cell Mol Biol 272:245-302

5. Aspengren S, Norström E, Wallin M (2012) Effects of hydroquinone on cytoskeletal organization and intracellular transport in cultured Xenopus laevis melanophores and fibroblasts.ISRN Cell Biol, 2012,1-8

6. Aspengren S, Wielbass L, Wallin M (2006) Effects of acrylamide, latrunculin, and nocodazole on intracellular transport and cytoskeletal organization in melanophores. Cell Motil Cytoskel 63:423436

7. Bach NC, Marino DJ, Natale GS, Somoza GM (2018) Effects of glyphosate and its commercial formulation, Roundup ${ }^{\circledR}$ Ultramax, on liver histology of tadpoles of the neotropical frog, Leptodactylus latrans (amphibia. Anura). Chemosphere 202:289-297

8. Bacolod ET, Uno S, Villamor SS, Koyama J (2017) Oxidative stress and genotoxicity biomarker responses in tilapia (Oreochromis niloticus) exposed to environmental concentration of 1nitropyrene. Mar Pollut Bull 124:786-791

9. Bagnara JT, Matsumoto J (2006) Comparative anatomy and physiology of pigment cells in non mammalian tissues. In: The Pigmentary System. Oxford University Press, $2^{\text {a }}$ ed. p1229, pp 11-59

10. Bargagli R, Corsolini S, Fossi MC, Martella L, Sanchez-Hernandez JC, Focardi S (1998) Antarctic fish Trematomus bernacchii as biomonitor of environmental contaminants at Terra Nova Bay Station (Ross Sea). Mem Natl Inst Polar Res Spec Issue 52:220-229

11. Bates D, Maechler M, Bolker B, Walker S (2015) Fitting linear, mixed-effects models using Ime4. J Stat Software 67:1e48

12. Bend JR (1994) Estimation of induction of enzymes that metabolize xenobiotics in vitro and in vivo. In: Renzoni A, Mattei N, Lari L, Fossi MC (eds) Contaminants in the environment. Lewis Publishers/ CRC Press, Boca Raton, pp 93-101

13. Bolker BM, Brooks ME, Clark CJ, Geange SW, Poulsen JR, Stevens MHH, White JSS (2009) Generalized linear mixed models: a practical guide for ecology and evolution. Trends Ecol Evol 24(3):127e135

14. Bonacci S, Corsi I, Chiea R, Regoli F, Focardi S (2003) Induction of EROD activity in European eel (Anguilla anguilla) experimentally exposed to benzo [a] pyrene and $\beta$-naphthoflavone. Environ Internl 
29(4):467-473

15. Brandt CA, Becker JM, Porta A (2002) Distribution of polycyclic aromatic hydrocarbons in soils and terrestrial biota after a spill of crude oil in Trecate. Italy Environ Toxicol Chem 21(8):1638e1643

16. Brinkmann M, Blenkle H, Salowsky H, Bluhm K, Schiwy S, Tiehm A, Hollert H (2014) Genotoxicity of heterocyclic PAHs in the micronucleus assay with the fish liver cell line RTL-W1. PloS One 9:e85692

17. Caruso MSF, Alaburda J (2008) Hidrocarbonetos policíclicos aromáticos e benzo(a)pireno: uma revisão. Ver Inst Adolfo Lutz 67(1):1e27

18. Collier TK, Anulacion BF, Arkoosh MR, Dietrich JP, Incardona JP, Johnson LL, Ylitalo GM, Myers MS (2013) Effects on Fish of Polycyclic Aromatic HydrocarbonS (PAHS) and Naphthenic Acid Exposures. Fish Physiology 33:195-255

19. Colombo S, Berlim I, Delmas V, Larue L (2011) Classical and non-classical melanocytes in vertebrates. In Melanins and Melanosomes: Biosynthesis, Biogenesis, Physiological and Pathological Functions, 1st edn (ed. J. Borovanský and P. A. Riley). p21-61

20. Connel DW (1990) Bioaccumulation of xenobiotics compounds. CRC Press, Boca Raton

21. Crawley MJ (2012) The R Book. John Wiley \& Sons, London

22. Curtis LR, Garzon CB, Arkoosh M, Collier T, Myers MS, Buzitis J, Hahn ME (2011) Reduced cytochrome P4501A activity and recovery from oxidative stress during subchronic benzo[a]pyrene and benzo[e]pyrene treatment of rainbow trout. Toxicol Appl Pharmacol 254(1):1-7

23. De Oliveira C, Franco-Belussi L, Fanali LZ, Santos LRS (2017) Chapter 6: Use of Melanin-pigmented Cells as a New Tool to Evaluate Effects of Agrochemicals and Other Emerging Contaminants in Brazilian Anurans, p. 125-139. Section II: Terrestrial Vertebrates as Experimental Models. In: Ecotoxicology and Genotoxicology Non-traditional Terrestrial Models. (Ed. Marcelo L. Larramendy). eBook (Print ISBN: 978-1-78262-811-8) Royal Society of Chemistry, Cambridge, UK

24. Denison MS, Nagy SR (2003) Activation of the aryl hydrocarbon receptor by structurally diverse exogenous and endogenous chemicals. Annu Rev Pharmacol Toxicol 43:309-334

25. Douben P (2003) PAHs: An Ecotoxicological Perspective. John Wiley and Sons: New York

26. Ellesat KS, Tollefsen KE, Åsberg A, Thomas KV, Hylland K (2010) Cytotoxicity of atorvastatin and simvastatin on primary rainbow trout (Oncorhynchus mykiss) hepatocytes. Toxicol in Vitro 24(6):1610-1618

27. Fanali LZ, Franco-Belussi L, Bonini-Domingos CR, de Oliveira C (2018) Effects of benzo[a]pyrene on the blood and liver of Physalaemus cuvieri and Leptodactylus fuscus (Anura: Leptodactylidae). Environ Poll, 237, 93-102

28. Fanali LZ, Valverde BSL, Franco-Belussi L, Provete DB, de Oliveira C (2017) Response of digestive organs of Hypsiboas albopunctatus (Anura: Hylidae) to benzo[a]pyrene. Amphib-Reptil 38:175e185

29. Fenoglio C, Boncompagni E, Fasola M, Gandini C, Comizzoli S, Milanesi G, Barni S (2005) Effects of environmental pollution on the liver parenchymal cells and Kupffer-melanomacrophagic cells of the frog Rana esculenta. Ecotoxicol Environ Saf 60:259e268 
30. Fishelson L (2006) Cytomorphological alterations of the thymus, spleen, head-kidney, and liver in cardinal fish (Apogonidae, Teleostei) as bioindicators of stress. J Morphol 267(1):57e69

31. Forlin L, Haux C, Karlsson-Norrgren L, Runn P, Larsson A (1986) Biotransformation enzyme activities and histopathology in rainbow trout (Salmo gairdneri) treated with cadmium. Aquat Toxicol 8(1):5164

32. Fournie JW, Summers JK, Courtney LA, Engle VD (2001) Utility of splenic macrophage aggregates as an indicator of fish exposure to degraded environments. J Aquat Anim Health 13(2):105e116

33. Franco-Belussi L, Sköld HN, de Oliveira C (2016) Internal pigment cells respond to external UV radiation in frogs. J Exp Biol, jeb-134973

34. Goksøyr A, Förlin L (1992) The cytochrome P-450 system in fish, aquatic toxicology and environmental monitoring. Aquat Toxicol 22(4):287-311

35. Hariri M, Mirvaghefi A, Farahmand H, Taghavi L, Shahabinia AR (2018) In situ assessment of Karaj River genotoxic impact with the alkaline comet assay and micronucleus test, on feral brown trout (Salmo trutta fario). Environ Toxicol Pharmacol 58:59-69

36. Haux C, Forlin L (1988) Biochemical methods for detecting effects of contaminants on fish. Ambio 17(6):376-380

37. Head JA, Jeffery RW, Farmahin R, Kennedy SW (2015) Potency of polycyclic aromatic hydrocarbons (PAHs) for induction of ethoxyresorufin-O-deethylase (EROD) activity in hepatocyte cultures from chicken, Pekin duck, and greater scaup. Environ Sci Technol 49(6):3787-3794

38. Hedberg D, Wallin M (2010) Effects of roundup and glyphosate formulations on intracellular transport, microtubules and actin filaments in Xenopus laevis melanophores. Toxicol inVitro 24:795802

39. Joo DH, Cha HJ, Kim K, Jung M, Ko JM, Na IS, Ahn KJ (2015) Benzo(a)pyrene represses melanogenesis in B16F10 mouse melanoma cells. Mol Cell Toxicol 11(3):349e355

40. Kaur R, Shah TK, Kaur S, Rani S (2018) A review on genotoxicity in aquatic organisms and environment. J Pharm Innov 7(1):353-359

41. Kenward MG, Roger JH (1997) Small sample inference for fixed effects from restricted maximum likelihood. Biometrics 53:983e997

42. Koyama Y, Takeuchi T (1980) Differential effect of cytochalasin B on the aggregation of melanosomes in cultured mouse melanoma cells. Anat Rec 196:449-459

43. Laville N, Ait-Aissa S, Gomez E, Casellas C, Porcher JM (2004) Effects of human pharmaceuticals on cytotoxicity, EROD activity and ROS production in fish hepatocytes. Toxicology 196(1/2):41-55

44. Lenth RV (2016) Least-squares means: the R package Ismeans. J Stat Software 69:1e33

45. Logan DT (2007) Perspective on Ecotoxicology of PAHs to Fish. Human Ecological Risk Assessment: An Int J 13:302-316

46. Loumbourdis NS, Vogiatzis AK (2002) Impact of cadmium on liver pigmentary system of the frog Rana ridibunda. Ecotoxicol Environ Saf 53(1):52e58 
47. Lowry OH, Rosebrough NJ, Farr AL, Randall RJ (1951) Protein measurement with the Folin phenol reagent. J Bio Chem 193:265-275

48. Lüdecke D (2016) sjPlot: Data Visualization for Statistics in Social Science. R Package Version 2.1.2. Available from: https://CRAN.R-project.org/ package1/4SjPlot

49. Madureira DJ, Weiss FT, Van Midwoud P, Helbling DE, Sturla SJ, Schirmer K (2014) Systems toxicology approach to understand the kinetics of benzo (a) pyrene uptake, biotransformation, and DNA adduct formation in a liver cell model. Chem Res Toxicol 27(3):443e453

50. Malmström CM, Koponen K, Lindström-Seppä P, Bylund G (2004) Induction and localization of hepatic CYP4501A in flounder and rainbow trout exposed to benzo[a]pyrene. Ecotoxicol Environ Saf 58:365-372

51. McGuire J, Moellmann G, McKeon F (1972) Cytochalasin B and pigment granule translocation. J Cell Biol 52:754-758

52. Moen EL, Fricano-Kugler CJ, Luikart BW, O'Malley AJ (2016) Analyzing clustered data: why and how to account for multiple observations nested within a study participant? PLoS One 11(1):e0146721

53. Mouchet F, Gauthier L, Mailhes C, Ferrier V, Devaux A (2005) Comparative study of the comet assay and the micronucleus test in amphibian larvae (Xenopus laevis) using benzo(a)pyrene, ethyl methanesulfonate, and methyl methanesulfonate: establishment of a positive control in the amphibian comet assay. Environ Toxicol 20(1):74e84

54. Pacheco M, Santos MA (1998) Induction of liver EROD and erythrocytic nuclear abnormalities by cyclophosphamide and PAHs in Anguilla anguilla L. Ecotoxicol Environ Saf 40(1-2):71-76

55. Padrós J, Pelletier É, Ribeiro CO (2003) Metabolic interactions between low doses of benzo[a]pyrene and tributyltin in arctic charr (Salvelinus alpinus): a long-term in vivo study. Toxicol Appl Pharm 192:45-55

56. Pannetier P, Morin B, Clérandeau C, Lacroix C, Cabon J, Cachot J, Danion M (2019) Comparative biomarker responses in Japanese medaka (Oryzias latipes) exposed to benzo[a]pyrene and challenged with betanodavirus at three different life stages. Sci Total Environ 652:964-976

57. Park HY, Kosmadaki M, Yaar M, Gilchrest BA (2009) Cellular mechanisms regulating human melanogenesis. Cell Mol Life Sci 66(9):1493e1506

58. Pastore AS, Santacroce MP, Narracci M, Cavallo RA, Acquaviva MI, Casalino E, ... \& Crescenzo G (2014) Genotoxic damage of benzo[a]pyrene in cultured sea bream (Sparus aurata L.) hepatocytes: Harmful effects of chronic exposure. Mar Environ Res 100:74-85

59. Payne JF, Fancey LF (1989) Effect of polycyclic aromatic hydrocarbons on immune responses in fish: Change in melanomacrophage centers in flounder (Pseudopleuronectes americanus) exposed to hydrocarbon-contaminated sediments. Mar Environ Res 28(1):431-435

60. Peixoto MS, da Silva Junior FC, de Oliveira Galvão MF, Roubicek DA, de Oliveira Alves N, de Medeiros SRB (2019) Oxidative stress, mutagenic effects, and cell death induced by retene. Chemosphere 231:518-527 
61. Pérez-Iglesias JM, de Arcaute CR, Nikoloff N, Dury L, Soloneski S, Natale GS, Larramendy ML (2014) The genotoxic effects of the imidacloprid-based insecticide formulation Glacoxan Imida on Montevideo tree frog Hypsiboas pulchellus tadpoles (Anura, Hylidae). Ecotoxicol Environ Saf 104:120e126

62. Pronina SV, Batueva MD, Pronin NM (2014) Characteristics of melanomacrophage centers in the liver and spleen of the roach Rutilus rutilus (Cypriniformes: Cyprinidae) in Lake Kotokel during the Haff disease outbreak. J Ichthyol 54(1):104-110

63. R Core Team (2016) R: A language and environment for statistical computing. R Foundation for Statistical Computing, Vienna, Austria. URLhttps://www.Rproject.org/

64. Regnault C, Willison J, Veyrenc S, Airieau A, Méresse P, Fortier M, ... Reynaud S (2016) Metabolic and immune impairments induced by the endocrine disruptors benzo [a] pyrene and triclosan in Xenopus tropicalis. Chemosphere 155:519-527

65. Regnault C, Worms IA, Oger-Desfeux C, MelodeLima C, Veyrenc S, Bayle ML, Reynaud S (2014) Impaired liver function in Xenopus tropicalis exposed to benzo[a]pyrene: transcriptomic and metabolic evidence. BMC Genomics 15(1):666

66. Ribeiro HJ, Procópio MS, Gomes JMM, Vieira FO, Russo RC, Balzuweit K et al (2011) Functional dissimilarity of melanomacrophage centres in the liver and spleen from females of the teleost fish Prochilodus argenteus. Cell Tissue Res 346(3):417e425

67. Rodionov VI, Gyoeva FK, Gelfand VI (1991) Kinesin is responsible for centrifugal movement of melanosome granules in melanophores. Proc Natl Acad Sci USA 88(11):4956-4960

68. Rogers SL, Karcher RL, Roland JT, Minin AA, Steffen W, Gelfand VI (1999) Regulation of melanosome movement in the cell cycle by reversible association with myosin V. J Cell Biol 146(6):1265-1276

69. Rogers SL, Tint IS, Gelfand VI (1998) [30] In Vitro motility assay for melanophore pigment organelles. In Methods in enzymology, 298, p. 361-372. Academic Press

70. Rozdzial MM, Haimo LT (1986) Reactivated melanophore motility: differential regulation and nucleotide requirements of bidirectional pigment granule transport. J Cell Biol 103(6):2755-2764

71. Sammak PJ, Adams SR, Harootunian AT, Schliwa M, Tsien RY (1992) Intracellular cyclic AMP not calcium, determines the direction of vesicle movement in melanophores: direct measurement by fluorescence ratio imaging. J Cell Biol 117(1):57-72

72. Santana MS, Sandrini-Neto L, Filipak Neto F, Ribeiro O, Di Domenico CA, Prodocimo M, M.M (2018) Biomarker responses in fish exposed to polycyclic aromatic hydrocarbons (PAHs): Systematic review and meta-analysis. Environ Pollut 242:449-461

73. Santos LRS, Franco-Belussi L, Zieri R, Borges RE, de Oliveira C (2014) Effects of Thermal Stress on Hepatic Melanomacrophages of Eupemphix nattereri (Anura). Anat Rec 297:864-875

74. Schreer A, Tinson C, Sherry JP, Schirmer K (2005) Application of Alamar blue/5-carboxyfluorescein diacetate acetoxymethyl ester as a non invasive cell viability assay in primary hepatocytes from rainbow trout. Anal Biochem 344(1):76-85 
75. Sichel G, Scalia M, Mondio F, Corsaro C (1997) The amphibian kupffer cells build and demolish melanosomes: an ultrastructural point of view. Pig Cell Res 10:271-287

76. Sköld HN, Norström E, Wallin M (2002) Regulatory control of both microtubule-and actin-dependent fish melanosome movement. Pig Cell Res 15(5):357-366

77. Sköld HN, Aspengren S, Cheney KL, Wallin M (2016) Fish chromatophores-from molecular motors to animal behavior. In International Review of Cell and Molecular Biology, 321, p. 171-219). Academic Press

78. Sturve J, Balk L, Liewenborg B, Adolfsson-Erici M, Förlin L, Almroth BC (2014) Effects of an oil spill in a harbor assessed using biomarkers of exposure in eelpout. Environ Sci Poll Res 21(24):1375813768

79. Tuma MC, Gelfand VI (1999) Molecular mechanisms of pigment transport in melanophores. Pig Cell Res 12(5):283-294

80. Van der Oost R, Beyer J, Vermeulen NP (2003) Fish bioaccumulation and biomarkers in environmental risk assessment: a review. Environ Toxicol Pharmacol 13(2):57-149

81. Videira IFDS, Moura DFL, Magina S (2013) Mechanisms regulating melanogenesis. An Bras Dermatol 88(1):76e83

82. Wakx A, Regazzetti A, Dargère $D$, Auzeil N, Gil S, Evain-Brion D, Rat $P(2016)$ New in vitro biomarkers to detect toxicity in human placental cells: the example of benzo [a] pyrene. Toxicol Vitro 32:76e85

83. Whyte JJ, Jung RE, Schmitt CJ, Tillitt DE (2000) Ethoxyresorufin-O-deethylase (EROD) activity in fish as a biomarker of chemical exposure. Critical Rev Toxicol 30(4):347-570

84. Wolke RE (1992) Piscine macrophage aggregates: a review. Annual Ver Fish Dis 2:91e108

85. Yeo CD, Kim YA, Lee HY, Kim JW, Kim SJ, Lee SH, Kim YK (2017) Roflumilast treatment inhibits lung carcinogenesis in benzo(a)pyrene-induced murine lung cancer model. Eur J Pharmacol 812:189-195

86. Zuasti A, Jara JR, Ferre C, Solano F (1989) Occurrence of melanin granules and melanosynthesis in the kidney of Sparus auratus. Pig Cell Res 2(2):93e99

87. Zuur AF, leno EN, Walker N, Saveliev AA, Smith GM (2009) Mixed Effects Models and Extensions in Ecology. Springer, New York

\section{Figures}


1200

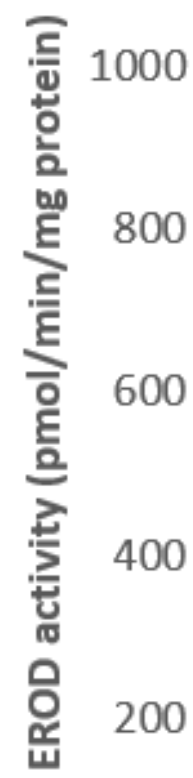

0

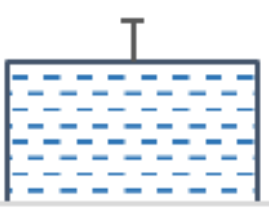

Cont $48 \mathrm{~h}$

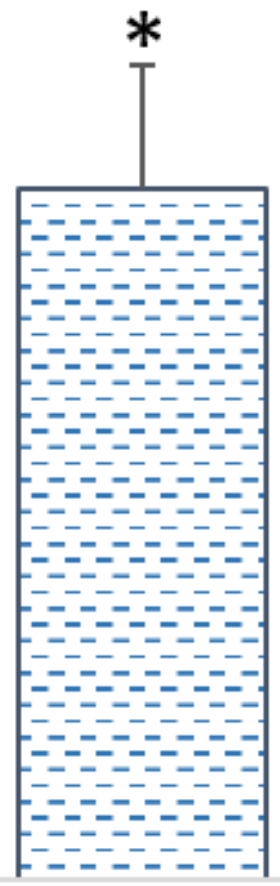

$\mathrm{BaP} 48 \mathrm{~h}$

\section{Figure 1}

EROD activity in rainbow trouts exposed to $2 \mathrm{mg} / \mathrm{kg}$ of benzo[a]pyrene for 48 hours ( $48 \mathrm{~h}$ ). An asterisk indicates significant differences between treatments $(P<0.05)$. Cont $=$ peanut oil, $\mathrm{BaP}=$ benzo[a]pyrene . 


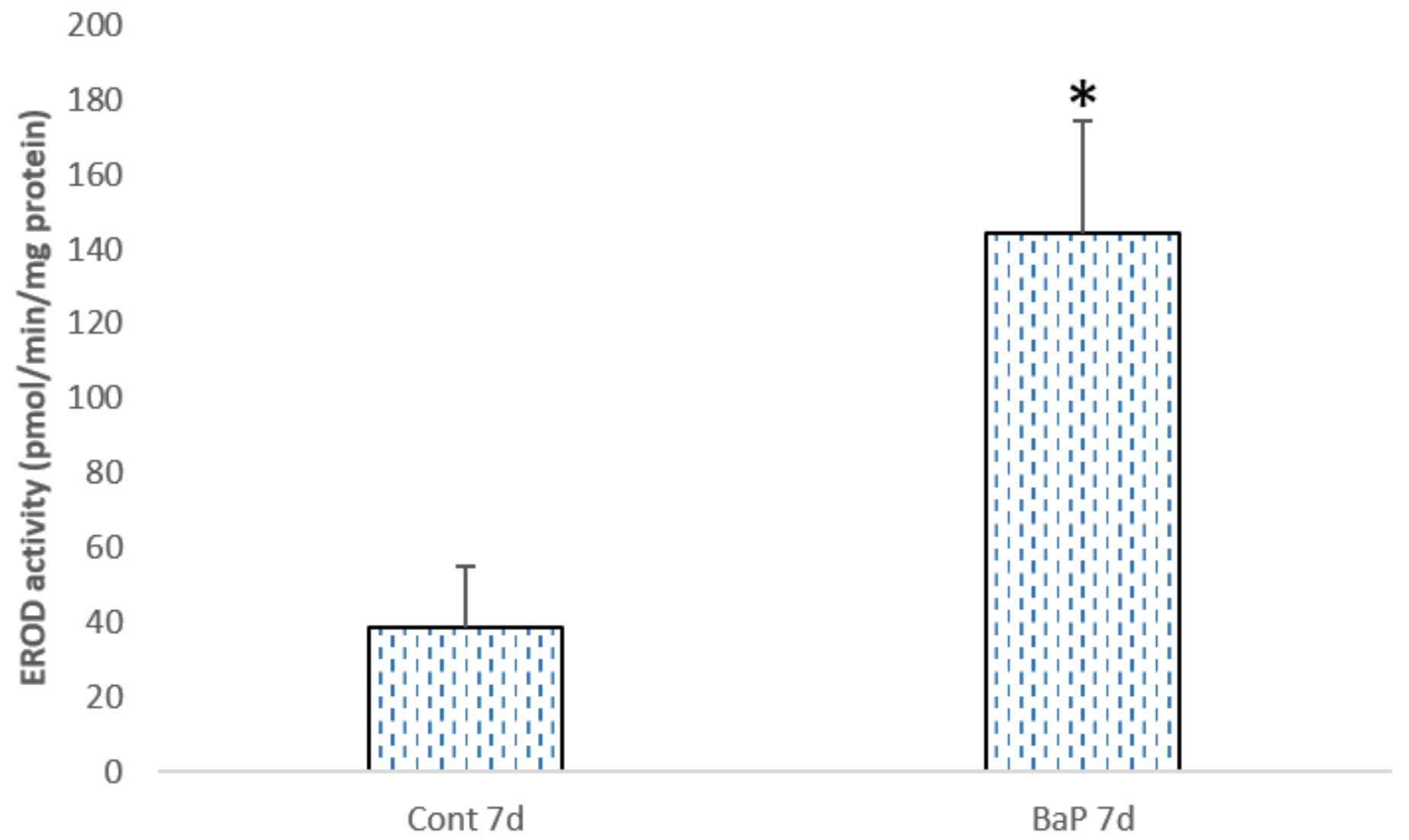

Figure 2

EROD activity in rainbow trouts exposed to $2 \mathrm{mg} / \mathrm{kg}$ of benzo[a]pyrene for 7 days (7d). An asterisk indicates significant differences between treatments $(P<0.05)$. Cont $=$ peanut oil, $\mathrm{BaP}=$ benzo[a]pyrene. 


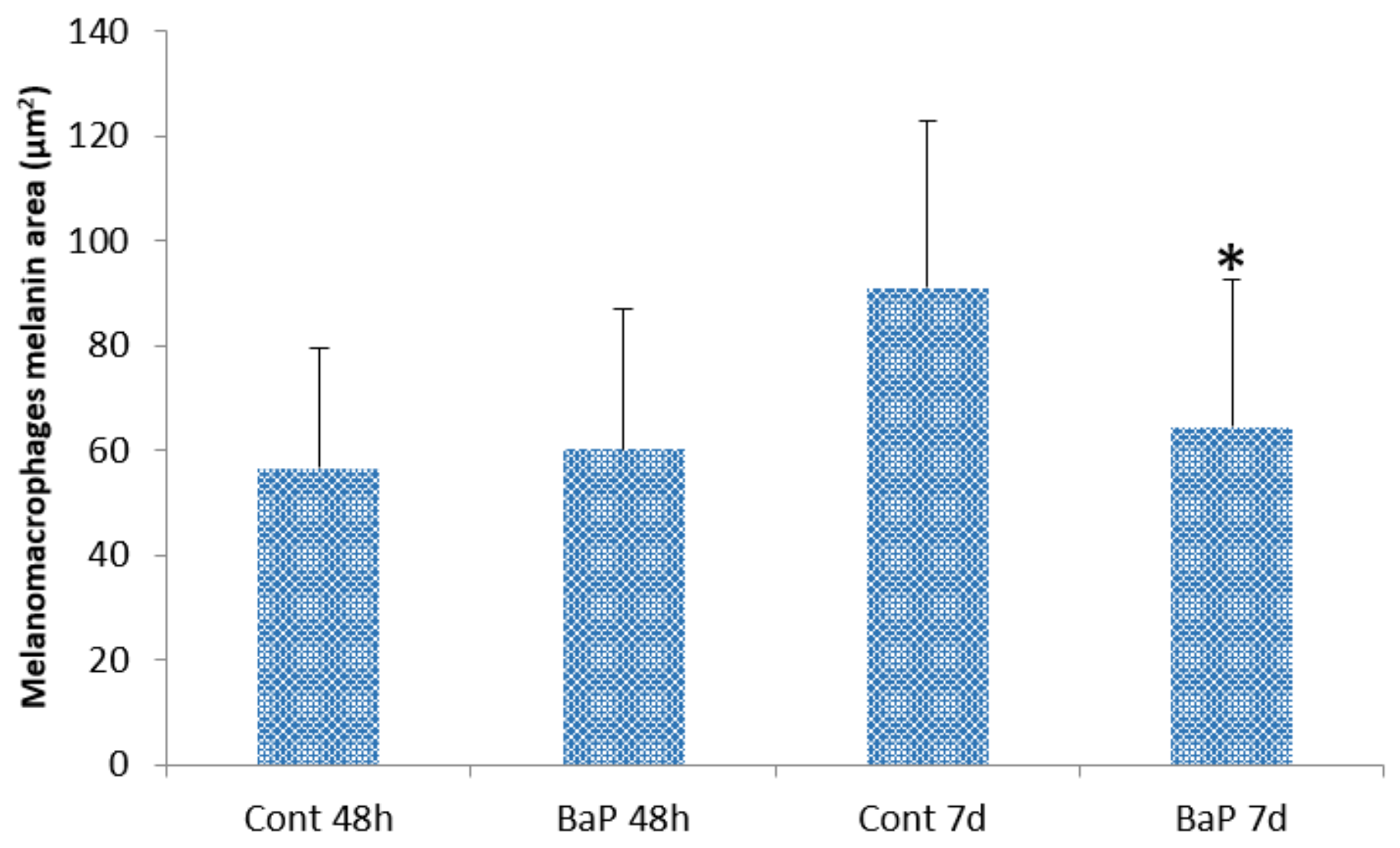

Figure 3

Melanin area of melanomacrophages in rainbow trouts exposed to $2 \mathrm{mg} / \mathrm{kg}$ of benzo[a]pyrene for 48 hours (48h) and 7 days (7d). An asterisk indicates significant differences among treatments $(P<0.05)$. Cont $=$ mineral oil, $\mathrm{BaP}=$ benzo[a]pyrene . 


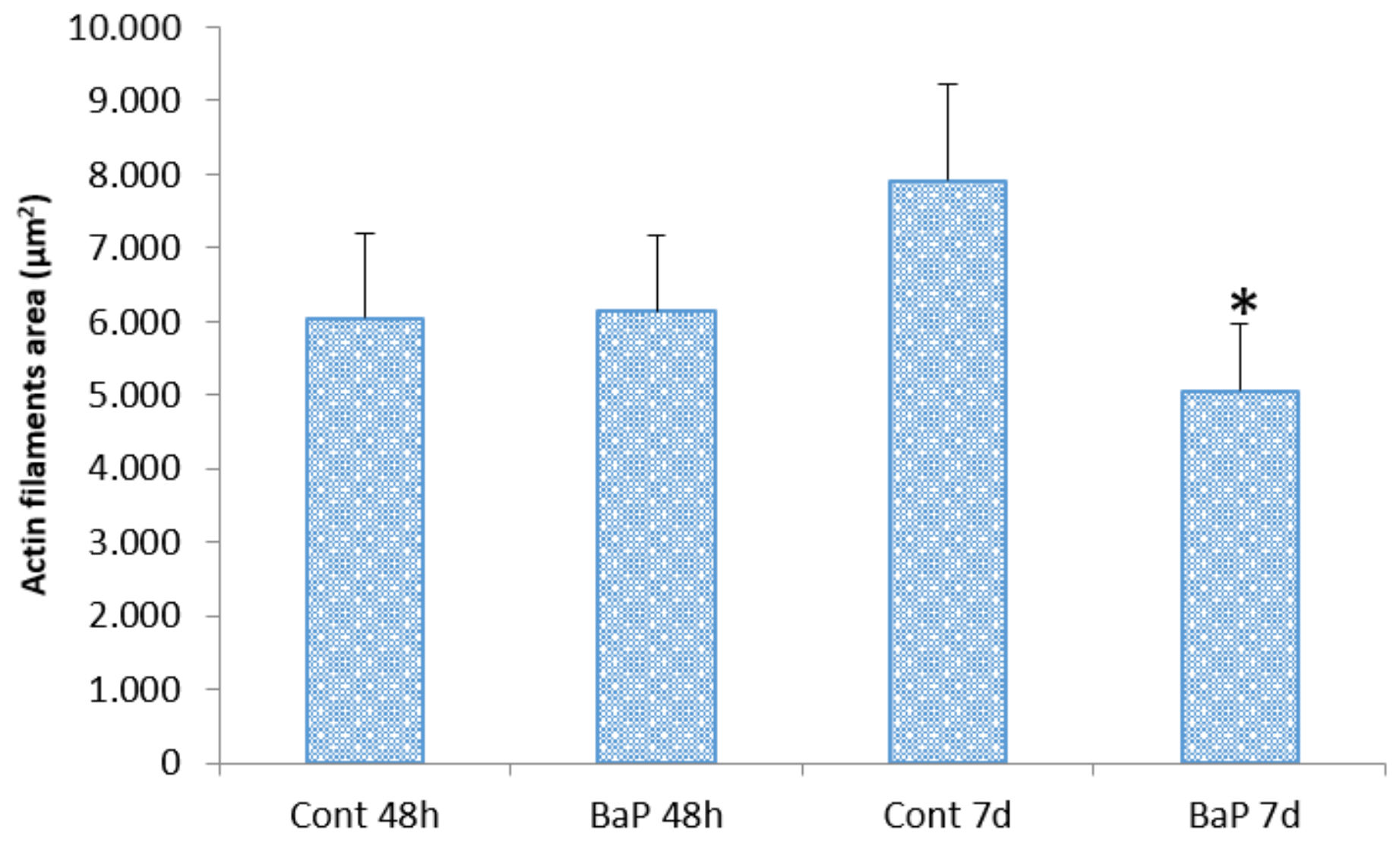

Figure 4

Fluorescent cell area corresponding to actin filaments of rainbow trouts exposed to $2 \mathrm{mg} / \mathrm{kg}$ of benzo[a]pyrene for 48 hours (48h) and 7 days (7d). An asterisk indicates significant differences among treatments $(P<0.05)$. Cont $=$ peanut oil, $\mathrm{BaP}=$ benzo[a]pyrene. 

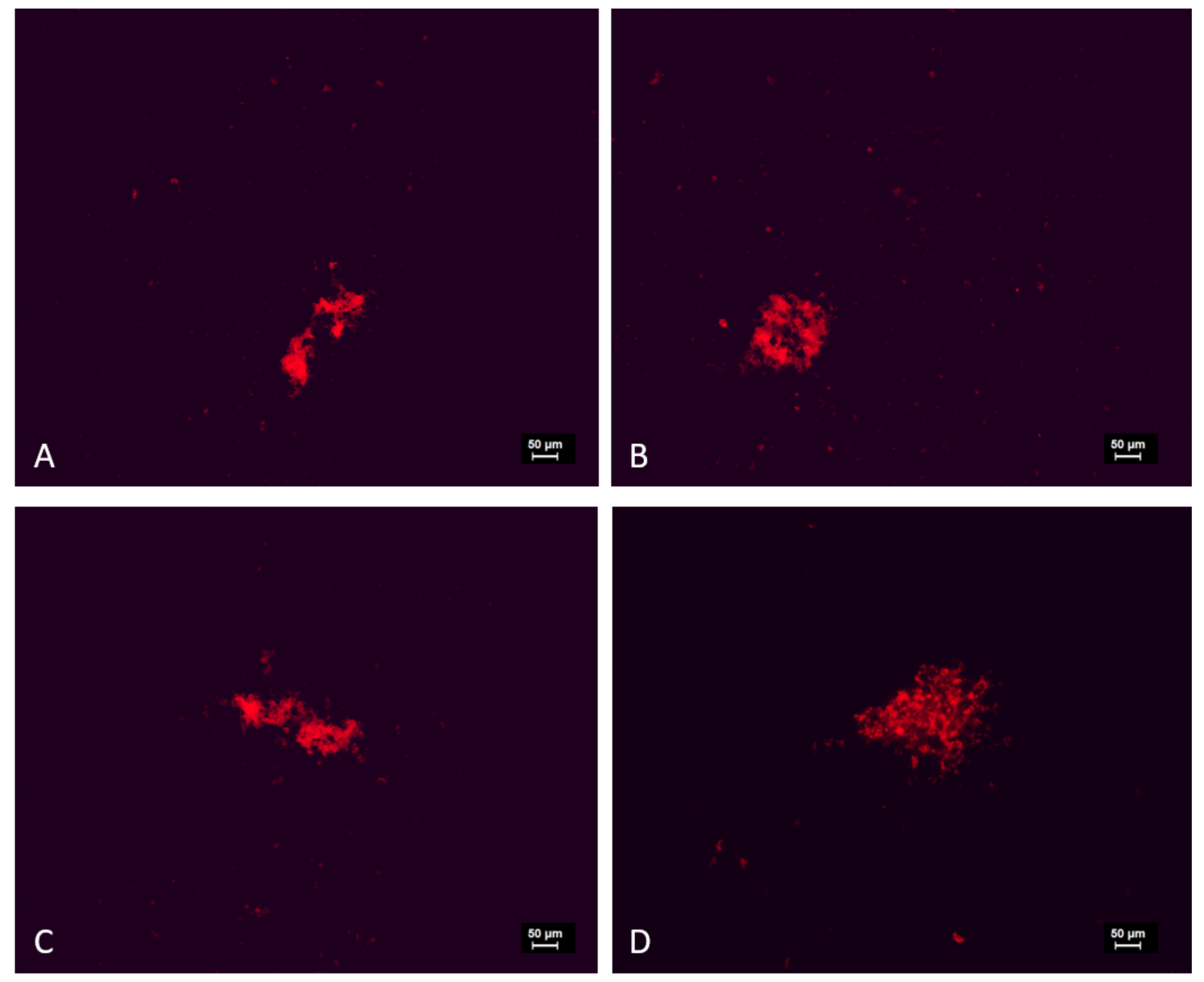

\section{Figure 5}

Immunofluorescence of rainbow trouts showing melanomacrophages aggregation/dispersion represented by actin filaments. A and C: aggregated melanosomes; B and D: dispersed melanosomes. Scale bar: $50 \mu \mathrm{m}$. 


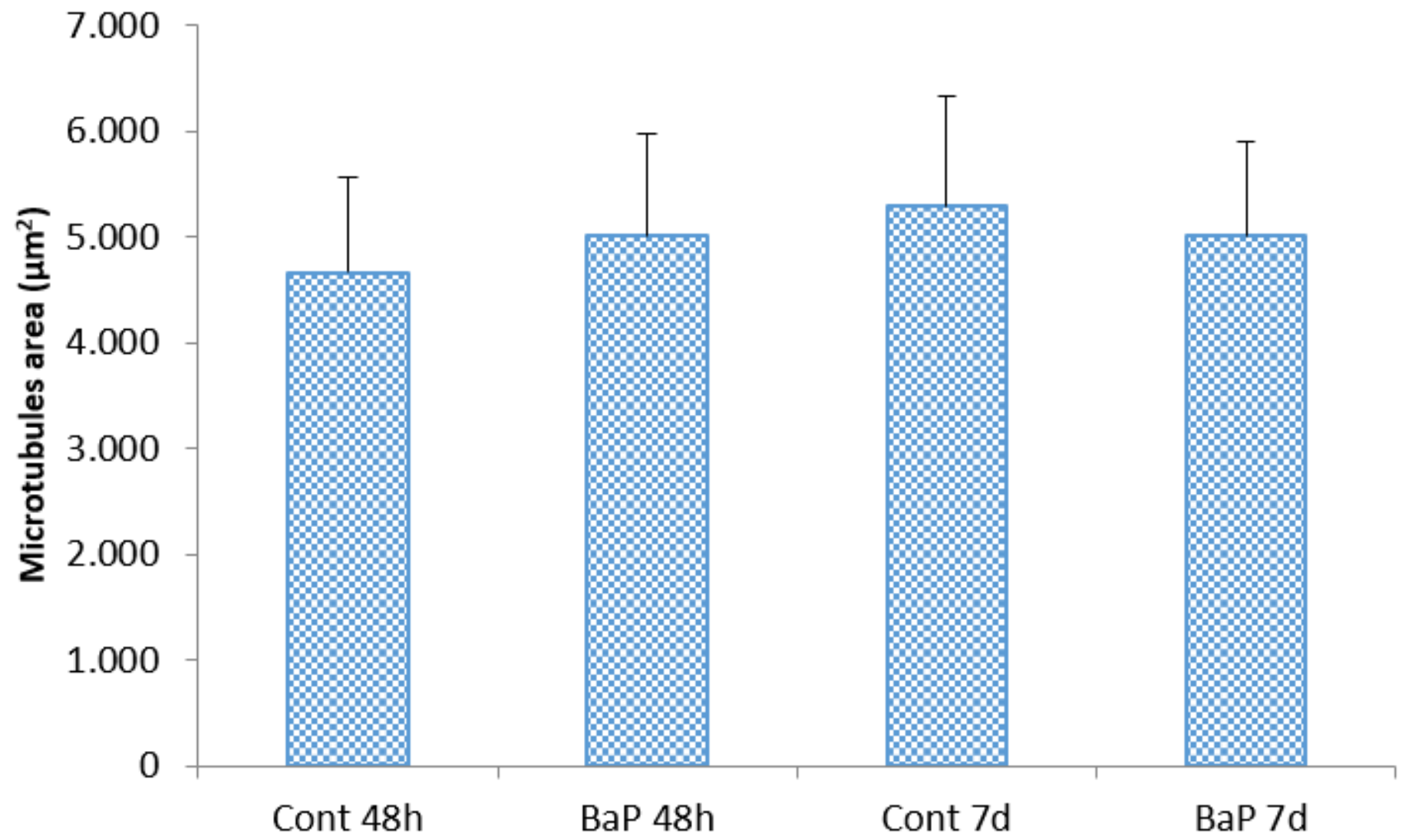

Figure 6

Fluorescent cell area corresponding to microtubules of rainbow trouts exposed to $2 \mathrm{mg} / \mathrm{kg}$ of benzo[a]pyrene for 48 hours (48h) and 7 days (7d). No statistical differences were observed $(P>0.05)$. Cont $=$ peanut oil, $\mathrm{BaP}=$ benzo[a]pyrene. 

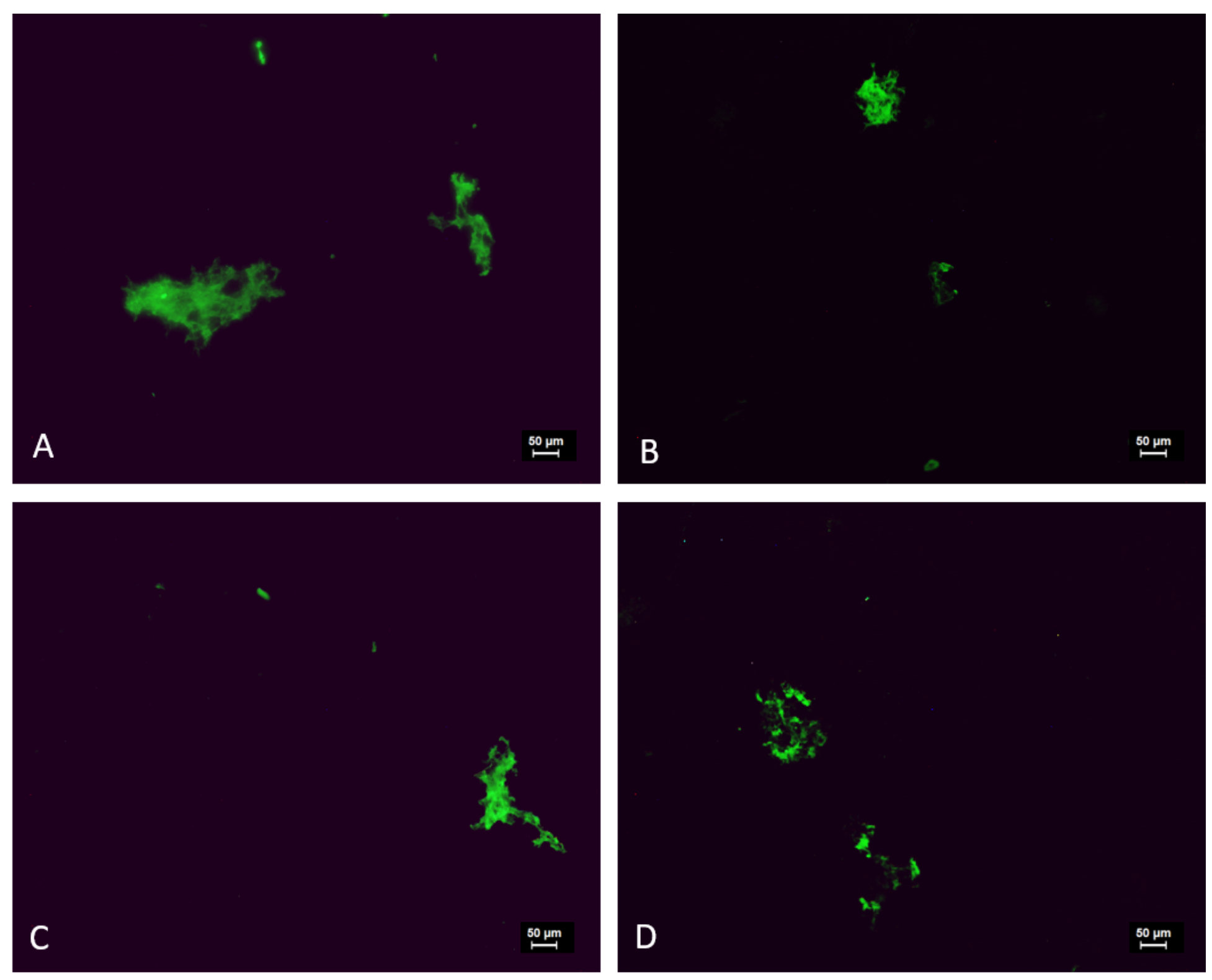

\section{Figure 7}

Immunofluorescence of rainbow trout cells showing melanomacrophages aggregation/dispersion represented by microtubules. A: dispersed (left side) and aggregated (right side) melanosomes; B: dispersed melanosomes; C: aggregated melanosomes; D: dispersed (left side) and aggregated (right side) melanosomes. Scale bar: $50 \mu \mathrm{m}$.
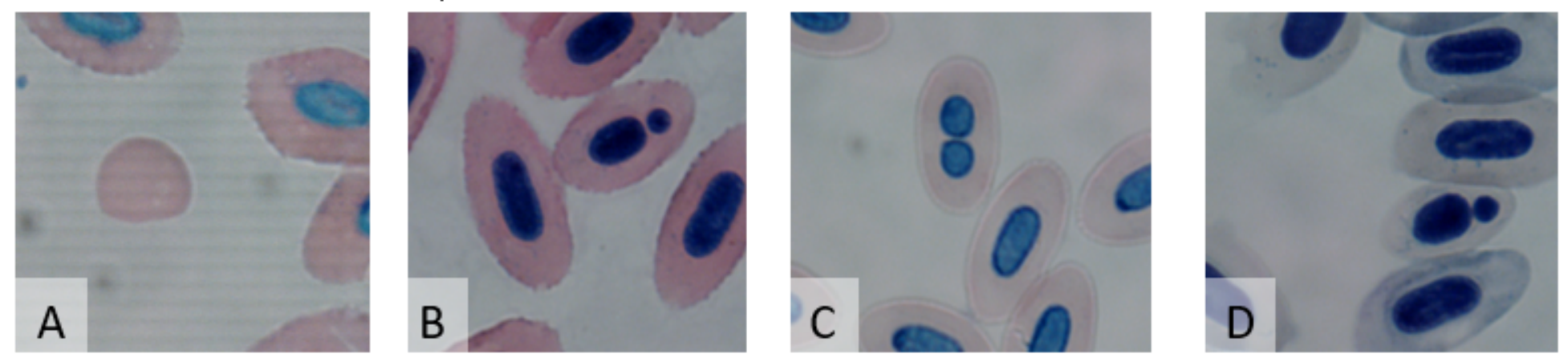
Figure 8

Rainbow trout erythrocytes. A: anucleate, B: Micronucleus, C: binucleated, D: Bud. 